\title{
"Trust facilitates business, but may also ruin it": the hazardous facets of Sino-Vietnamese border trade
}

\section{Caroline Grillot}

To cite this article: Caroline Grillot (2016) "Trust facilitates business, but may also ruin it": the hazardous facets of Sino-Vietnamese border trade, Asian Anthropology, 15:2, 169-185, DOI: 10.1080/1683478X.2016.1216281

To link to this article: https://doi.org/10.1080/1683478X.2016.1216281

\section{(c) 2016 The Author(s). Published by Informa UK Limited, trading as Taylor \& Francis} Group

\section{曲 Published online: 08 Sep 2016.}

Submit your article to this journal $₫$

山ll Article views: 176

Q View related articles $\sqsubset$

View Crossmark data $₫$

4 Citing articles: 4 View citing articles 


\title{
"Trust facilitates business, but may also ruin it": the hazardous facets of Sino-Vietnamese border trade
}

\author{
Caroline Grillot*
}

Max Planck Institute for Social Anthropology, Halle, Germany

\begin{abstract}
This article focuses on the operational dynamic of informal small-scale trade in the Sino-Vietnamese borderlands as disclosed by local traders' strategies of negotiation. It questions the impact of financial transaction practices - management of official fees and procedures related to payments - on the sustainability of cross-border trade. It engages with the notion of "trust" and stresses its significance in a space where the vagaries of trade policies challenge business rules, and contest the local power hierarchy. It argues that despite the principles underlying "trustful cooperation" being unevenly adhered to, traders manage to adjust to one another's methods, revealing the nature of their tacit complicity in maintaining business logistics regardless of the limits imposed by national policies, institutional regulations and stereotypes.
\end{abstract}

Keywords: cross-border trade; trust; money transaction; informal economy; Sino-Vietnamese borderlands

\section{Introduction}

The trading cities of Móng Cái (Quang Ninh Province, Vietnam) and Dongxing (Guangxi Province, China) both constitute a cross-border economic cooperation district officially named the Dongxing-Móng Cái Free Trade Zone, a key strategic element of regional economic development and transnational integration in the Greater Mekong Subregion. Since there is great diversity among cross-border traders (Cheung 2000; Chan 2013), this article focuses on traders who operate small-scale businesses in the main Móng Cái market. These traders sell a diverse range of goods - clothes, electric appliances, medicine, etc. - and negotiate prices with their customers on a daily basis. I concentrate in particular on the critical perspective of established Chinese traders in Móng Cái who are smuggling their goods from China, and who have disclosed to me the operational dynamic of this informal trade. The analysis is based on data collected during three months of fieldwork in both Móng Cái and Dongxing, and a long-term familiarity with the Sino-Vietnamese borderland communities where I have conducted research projects regularly over the last ten years. After introducing the particular setting where Sino-Vietnamese border economic activities occur, I provide traders' insights into the strategies of negotiation. These insights question the impact of financial transaction practices, including management of the fees that frame business (rent, tax, shipping), and procedures related to payments for traded goods on the sustainability of cross-border trade. Drawing on ethnographic examples, the final section of this article engages with the key concept of trust in a Chinese context or xinyong. This stresses how central the issue of trust is in a space where the uncertainties and vagaries of trade and state

\footnotetext{
*Email: carolinegrillot@hotmail.com

(C) 2016 The Author(s). Published by Informa UK Limited, trading as Taylor \& Francis Group

This is an Open Access article distributed under the terms of the Creative Commons Attribution License (http:// creativecommons.org/licenses/by/4.0/), which permits unrestricted use, distribution, and reproduction in any medium, provided the original work is properly cited.
} 
policies challenge business ethics and rules, and contest the local power hierarchy. This article argues that despite the principles underlining "trustful cooperation" being unevenly adhered to, many traders do manage to overcome difficulties and adjust to one another's methods, and that the issue of "trust" must be considered against the background of growing economic development in this region.

\section{The fragile balance of the border economy}

Borderlands are often places of disorder regulated by informal rules and local interpretations of state regulations (Horstmann and Wadley 2006). In their Companion to Border Studies, Wilson and Donnan $(2012,17)$ draw on the recent scholarship on borders and propose to conceptualize them "as processes, as floating signifiers, as waypoints and conduits in the flow of peoples, ideas, goods, capital and threats to the body politic." In this context, licit trade and illicit activities all occur simultaneously and their nature changes according to variations of circumstances. As Abraham and van Schendel (2005, 7) remind us, "official rules, structures, and discourses do posit a sharp distinction between law and crime, but it is essential to understand that this claim is only one element in the nexus of practices bridging the licit/illicit divide." In spaces such as Móng Cái and Dongxing, such an understanding is embedded in all the local trade praxis. In order to introduce the setting, the following is an overview of the core issues that underline the atmosphere surrounding small-scale trade, as experienced and articulated by the agents directly involved in business operations.

Issues of stability and security constantly emerge from the narratives of Chinese traders either established in Móng Cái or conducting cross-border trade in the area. $B u$ wending [unstable] and bu anquan [insecure] are words they use to express their feelings towards the local environment they must cope with in order to organize their business activities. The perplexities and worries they depict indicate three levels of insecurity. The state level comes first. In recent decades, and particularly during the time when the research that informs this article was conducted (2013-2014), several episodes marked a vivid resurgence of the never-ending question of sovereignty over maritime territories that both China and Vietnam claim to be theirs. Although the venues of these disputes are a long way from Móng Cái and Dongxing, the border area and the traders themselves are affected by the states' regular emphasis on unsolved historical issues. Frictions at the diplomatic level, spread throughout media and propaganda materials, regularly arouse suspicion and paranoia among people who have difficulty maintaining a critical distance from the manner in which geopolitical matters are explained and represented. As Zhang Juan $(2011,312)$ emphasizes,

[m]emory at the borderland is full of ambiguity; it is in a state of liminality that constantly vacillates between forgetfulness and remembrance. People by the border can never forget, nor fully remember, thereby dwelling at the edge of reminiscence as they strive forward.

In the borderlands, patriotism and nationalism always find a niche in which they can flourish among those eager to believe that the enemy is next door, precisely when frustrating everyday practices tend to provoke each other's distrust.

State propaganda maintains tension and provokes debates among locals, who see in any sudden strict implementation of regional policies and border trade rules the direct consequence of another diplomatic crisis. The instability of the geopolitical environment goes hand in hand with business precariousness. This is illustrated through unpredictable 
schedules of border controls, confiscation of merchandise, or feebleness and unreliability of business counterparts, some of the direct consequences of local authorities' decisions to follow the governmental guidelines and to tighten regulatory procedures. Operating businesses under such conditions undeniably creates a feeling of insecurity since traders and their direct logistical partners (paperwork negotiators and shippers) lose control over their activities, and the overall fluidity of trade dynamics. But delayed deliveries are not the only consequences of frontiers being overly scrutinized. Frozen food, for instance, gets directly affected by various delays on the shipping route. The extra expenses in electricity to keep the containers cold in border warehouses while waiting for permission to cross the border are at stake. Some transporters considered them to be too high of a risk for their budget and they sometimes sacrifice food security to increased storage costs, which may lead to freight abandonment. The anxiety created by the increasing instability of the diplomatic relationship and consequent variations in border management is also palpable in the local markets: closed shops, bored sellers, empty corridors, a lack of products, an inability to keep promises, and different disputes have recently been obvious signs of Chinese traders' discouragement.

But experienced traders know that diplomatic ups-and-downs only represent one side of the challenge in cross-border trade. Insecurity concerning the possibility of receiving goods from suppliers in China, and delivering them in time to Vietnamese clients also depends on the personal connections maintained by each trader, with business partners all along the shipping route, and on his/her capacity to overcome logistical difficulties so as to honor his/her contracts with customers. In terms of expenses, such exceptional arrangements may have consequences in terms of imposing additional financial pressure on already weakened traders. These costs include additional bribes to customs officers, border guards and market management employees. They also include extra investments in shipping through alternative routes organized by transporters and carriers who raise their prices in moments of diplomatic crisis inducing tightening control over border crossing; traders may find themselves exposed to various risks and subsequent penalties or crackdowns because of smuggling.

In Vietnam, Chinese people are aware that they attract little sympathy because of their dominating economic power. Even though not all of them believe in the Vietnamese military threat emphasized in Chinese propaganda discourse, they reportedly encounter acts of intimidation and various interferences in the regular processes of their business, including life threats, rendering them anxious and insecure. This is especially the case for those who lack the relevant connections to ease their everyday operations, and the capital to invest in bribes to deter harassment and those who face difficulties in the business project itself, independent of conjectural factors. This is the case for some Chinese traders who have established their wholesale shops in Móng Cái's Central Market, a place where the constant turnover of businesses indicates the difficulties many encounter in succeeding in a national market that requires constant adjustment.

There, the controversial management of trading spaces adds another layer of dissatisfaction to the general feeling of unease of Chinese wholesalers and shopkeepers. This constitutes the third level of insecurity. Business in Móng Cái's Central Market is conducted in large open spaces where shops are predominantly tiny and full of displayed wholesale products with a constant turnover. Business can be fast, especially in the morning when Vietnamese customers rush into the market to snap up good deals and organize shipments. In this quite chaotic dynamic, shop owners pay attention to every move (Figure 1). Experienced traders advised me of the existence of some very well organized thieves, who steal certain products with the presumed complicity of insiders. 


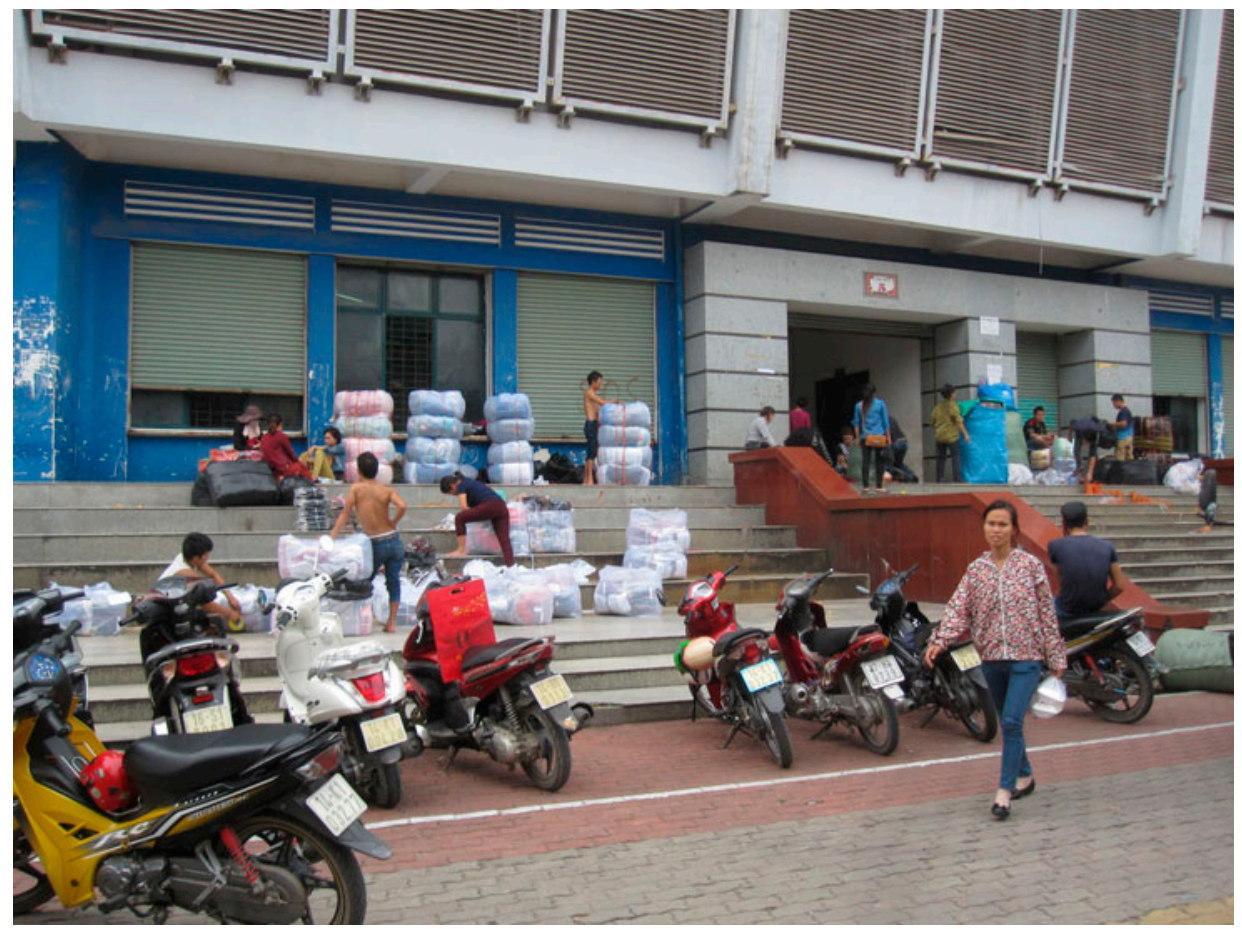

Figure 1. Outside Móng Cái's Central Market, packaging Chinese commodities for shipping through Vietnam (Photograph by Caroline Grillot 2013).

Stories of the complicity of acquaintances involving interpreters or market security guards abound and motivate traders to remain extra cautious and to avoid leaving valuable items in their shops overnight. Hence, at night, despite the presence of night watchmen, metallic shop doors and shop door padlocks, all shopkeepers keep a private strongbox inside which they store valuable products (such as mobile phones, electronic devices and cash). Many also choose to take their money to China on a daily basis (albeit within the limited allowable amounts).

The logistics of border trade necessitate a close collaboration with Chinese and Vietnamese agents, in the private sector as well as the state sector. However, in this particular market, relationships with management officers are oftentimes sensitive to negotiate. $\mathrm{Mr}$. $\mathrm{Wu}$, a women's garments shopkeeper in the Central Market, describes his perplexity regarding official demands:

Importing Chinese goods to Vietnam through official gates or smuggling channels exposes us to the payment of various shipping costs, including those paid to customs. But even after the goods arrive at the market, we must handle lots of other fees. In this market we pay different taxes: land tax, state tax, shop façade tax and management tax, and we also have various fees such as shop and storage rental, electricity, security, insurance (which we are forced to buy, for fear of seeing our shops destroyed by fire), and other occasional fees, such as for repairs (which are very high in terms of what they are paying for).

Each stallholder offered his/her own understanding of the variety of taxes collected in the market, and it became tricky to distinguish which of these applied to owners and 
which to renters of the stalls. Official figures were as difficult to obtain, and each market had its own management system. Three remarks were recurrent among Chinese traders: taxes they had to pay in order to enjoy a shop in a Vietnamese market space exceeded what they would pay in China for a similar setting; some occasional taxes were not quite "official"; and the visible outcome of the efforts made by taxpayers was non-existent or deemed as inadequate. Mr. Wu provides his perspective on market management:

\begin{abstract}
Market management tax supposedly contributes towards the protection of traders in the market during working hours, and overnight when the market is empty. This is a compulsory tax, and yet we don't feel protected. Fights often occur between customers and sellers, you know, about payments and returned goods most of the time. We call security if things turn violent, but no one appears. They are around but they choose not to react... until they feel things may get out of control. Then, they intervene to penalize the shopkeeper. Even if the customer is in the wrong, security usually protects them; then, if a Chinese trader complains or refuses to pay a fine for "disturbing the market," that trader's shop will be closed until he complies. Is this protecting us? I don't get it. They need our business to develop the city and provide Vietnam with affordable industrial goods, but their management only dissuades us from staying here. What's the benefit for the country?
\end{abstract}

Chinese traders generally live on the Chinese side of the border, for convenience and for safety reasons, as they see Vietnamese border cities as relatively insecure and backward in many senses. Allegations of regular armed robberies, the power of local mafia, and the corruption of local authorities prevent most Chinese from staying any longer than necessary each day in the Vietnamese borderland. Besides the environmental insecurity that underlies their articulation of a feeling of distrust, various aspects of trade-related activities act to sustain suspicion in the minds of Chinese traders. Maybe markets such as Móng Cái's Central Market are no less secure than similar market settings in China, but the flexibility and negotiation space within which they are able to resolve issues remains limited. This compels them to perceive their position as that of "victim" being abused by an unscrupulous and uncontrolled management. Issues of security constitute the ground on which business partners conduct negotiation, but here also mistrust tends to shape the exchanges and terms of agreements.

\title{
"A Yuan is a Yuan" - negotiating with the Vietnamese
}

In the context of market transactions, Vietnamese customers and their Chinese suppliers approach each other through the prism of an army of stereotypes related to their culture and their commercial ability. To ease exchanges and negotiations, most traders who do not speak their business partner's language rely on interpreters. Most interpreters are Vietnamese women who have learned Chinese, or who are of Chinese descent ("Hoa" Chinese from Vietnam), i.e. well connected in business circles on both side of the border and very much aware of cultural differences (Hai 2000). With their assistance, during negotiation both parties also rely on empirical observation to evaluate the degree of trust and reliance they can expect from their partner or, as Mick Moore articulates it in his attempt to conceptualize "trust," their mutual "predispositions to act in a certain way" $(1999,76)$.

Comments from Chinese traders reveal that the problematic issue of trust is very much linked to the understanding of values such as honesty and loyalty. This is especially true for Chinese migrant traders who felt unrelated to Vietnamese by cultural or 
historical common references. They perceive their business partners solely through the lens of the economy, and rarely endeavor to ground their mutual understanding, and bond their relationship beyond the limits of their transactions of commodities versus money. All that matters to traders is the ability of their customers to fulfill the moral obligations embedded in business deals, including those that could facilitate and sustain the setting of a long-term partnership in the pursuit of common interests. For instance, Chinese traders often complain about the negotiation skills of their Vietnamese customers: "To the Vietnamese, a yuan is a yuan, they are very thrifty"; "They hardly concede anything, even when we are old partners"; and "They don't understand what loyalty means." For Chinese traders, appearing flexible and even generous during a negotiation is an implicit business rule. While Vietnamese traders do not want to appear greedy, their Chinese counterparts perceive this reluctance to engage in any commercial gesture as an absence of business skills.

A Qiu, a Vietnamese trader of Chinese origin (a Hoa), runs a sport items business in Móng Cái and has years of experience in cross-border trade and transcultural interaction. He describes the different mechanisms:

Let us imagine a Chinese wholesaler who has a stock of clothes to sell. Each item cost him 5 yuan, including factory price and transportation cost, so he wants to sell each item for at least 10 yuan to make a good profit. He then sets his selling price at 10 yuan per item. Then a buyer comes and conducts a negotiation to get each item at a lower price than 10 yuan, while the seller tries to get an amount as close to 10 yuan as he can. Still, each party has a potential space of 5 yuan in which to bargain and reach an agreement. If they agree on 7 yuan, the buyer is satisfied (he lowered the initial price) and the seller makes a reasonable profit. But when a Vietnamese seller has goods to sell to a buyer, he acts differently. He directly sets a reasonable price rather than a highly profitable price. When asking for 7 or 8 yuan per item in the first place, he considers that this is already a good deal for him and for the buyer. The negotiation space is therefore very limited, and sometimes nonexistent. To Vietnamese traders, being too greedy does not represent an honest way in which to conduct business. They prefer to set a reasonable price to begin with and reach an agreement easily, so as to avoid the trouble of extended bargaining. In short, take it or leave it. On the contrary, a Chinese trader would rather negotiate and appear accommodating by conceding on a low price while in reality he has already made a significant profit.

In the above situation, when the original price of merchandise remains unknown, Chinese traders interpret the Vietnamese non-compromising attitude as an inability to conduct negotiation. To them, Vietnamese traders do not know how to bargain, are inflexible and are unable to adjust to their clients' expectations. They ignore the one basic rule of business: offer compromise to win the loyalty of new customers. However, Chinese traders provide two explanations for this behavior. Firstly, they attribute to Vietnamese people the inclination to be cunning and stingy, which interestingly is also attributed by Vietnamese to the Chinese (Endres 2015). Secondly, they refer to a delay in Vietnam's economic development, which anchors its people in a pre-liberalism mentality. "They act like Chinese people used to 20 or 30 years ago; they are inexperienced and do not know how to bargain" is a recurring comment heard among complainers. As condescending and simple as they may sound, these assumptions, among many other similar statements, show how different ways of dealing, especially when they are perceived as repetitive, can lead to widespread empirical accounts that translate annoyance and suspicion on both sides, and affect the mutual perception of business ethics and trust. 
Another recurring issue linked to negotiation is the perilous way in which payments are made. Delayed payments and repeated indebtedness undermine the whole mechanism of small-scale trade and constantly put at risk both parties involved. From the Chinese point of view, this becomes a crucial issue in their endeavor to establish or maintain reliable partnerships and retain regular Vietnamese customers. One of the main issues here is that business negotiations occur and the terms of payments are set without any safety net, or as Peebles $(2010,232)$ puts it, without "a regulatory authority or a common bond of trust that enforces it," a "precondition [that] represents one way in which credit/debt brings together temporal and spatial regulation." The general practice is that customers do not pay cash on the spot. They order, pay a deposit, pick up the goods, and promise to pay later. Because business is based on trust, without any written contract, whatever is agreed on the phone or during a business meeting is expected not to be retracted. However, Chinese wholesalers claim that Vietnamese customers often do not pay their debts on time, in violation of their oral agreements. They find reasons to delay payments, and they sometimes simply disappear without discharging their debts. This contributes to the establishment of a hierarchy between debtors and creditors that actually places power with the Vietnamese. How and why? The method employed by Vietnamese customers (whether a retailer in Vietnam or an intermediary representing one or several retailers) is apparently easy.

For example, a Vietnamese customer (an intermediary, usually a woman) orders a certain quantity of an article at one garment shop where she has bought clothes previously, and so she and the wholesaler already know each other. She pays a deposit and, when the goods are delivered, she pays another portion of the total price. Indebting herself, she leaves with the stock of articles and promises to pay the outstanding portion later. When the due time arrives, or when she needs to visit the same shop again, she explains to the wholesaler that she needs more time because she does not have the money (for various reasons). To avoid trouble, she orders another stock of items on behalf of another source (an order for another retailer for instance), who is possibly more important (showing her appreciation of the shop's clothes choice), pays another deposit, and leaves with the goods, leaving behind another installment in addition to the initial debt.

She proceeds in such a way that the Chinese wholesaler has no choice but to accept her conditions. If he/she does not, he/she risks losing the initial investment (since it may remain unpaid indefinitely), while still having to pay the garment factory in China where the order was placed; in addition, the wholesaler could lose a client with whom he/she has already dealt and placed trust in. On the other hand, if he/she accepts, there is a risk of entering into an endless cycle of unpaid debts and half-kept promises. Upon being pressured, the Vietnamese customer may well pay the outstanding amount due from one debt earlier, but the wholesaler nevertheless remains indebted. In addition to these risks, she may simply choose to change her supplier.

Mr Han comes from Guangdong province (China) and has been selling loungewear in Móng Cái's Central Market for a decade. He speaks Vietnamese and is very knowledgeable about doing business in Vietnam. He offers an explanation:

Vietnamese traders have little capital and so they need to invest and reinvest it without waiting for the benefit. This is why they pay for their orders with numerous small payments rather than one or two large ones. In the meantime, they can put the money towards another business deal if they feel there is better potential elsewhere. They adapt quickly. In many cases, the client of an intermediary also delays payments. It forces her to advance us the money for an order, in addition to shipment costs, which means she must indebt herself. 
Hence, intermediaries sometimes disappear without clearing their bills. Intermediaries also demand unusual things such as exaggerating the amount of an invoice, so that they can make more money at the expense of their own customers in Vietnam. Even though I don't like to support such practices, I must comply if I don't want to lose a customer... These practices also exist in China but in different proportions. I would say that in China 20 percent of deals face similar issues while the figure is 80 percent in Vietnam.

It is important for Chinese wholesalers to have capital, to enable them to order new products and remain competitive in the business. Many emphasize how their customers were honest at the beginning of their partnership, and slowly took the liberty of imposing delays in payment, even when business ethics require that all due debts should be cleared at least once a year, prior to the New Lunar Year. Song, a Chinese entrepreneur from Jiangxi who recently invested his family savings in opening a small shop in Móng Cái market feels stuck:

I am unlucky with this business. Some clients are honest but many don't respect our agreement and always ask for delay in paying their debt. I don't like this place, but how can I leave without being paid? Every day, I look for them to come back. Sometimes they pay a little, find excuses, and promise that the rest will come soon. They sometimes make a new order. So I need to import new clothes, and I may attract new customers; otherwise I don't make any money. I can't spend my time waiting, and I can't chase after them, they have local connections... I can't stop now.

Newcomers recognized how they had started business partnerships successfully enough to feel confident. Their customers fulfilled their payment obligations and respected the agreed-upon contracts. Based on such experience, they often become more adventurous and make additional investments and choices. But when they begin to face irregular payments from some clients, those whom they trusted, they usually find themselves already in a delicate position that forces them to stay until they get paid; otherwise they would lose their investment. Meanwhile, in order to survive economically, they engage in other deals to either secure the fragile relationship established with their indebted client, or in hopes of entering into transactions with other reliable customers.

It is interesting to note that Chinese traders feel that Vietnamese business people do not share their values and business principles, ignoring in their assessment the fact that these principles face irregularities in China as well. Nevertheless, these practices in the art of negotiation put the Chinese traders in a very uncomfortable position, which not only worries them and disrupts their commercial strategies and long-term investment plans, but also deters them from considering their Vietnamese customers as sustainable and reliable business partners.

When one decides, out of necessity or as driven by structural conditions, to conduct business outside of the formal channels of import-export, one might expect to work with no safety net, as in any site of informal economy (Stammler-Gossmann 2012). Trade is conducted on the basis of reliable, longstanding contacts, unwritten contracts, and trust. As one of the problem areas relates to capital flow, prior to discussing the core issue of trust let us first explore the issue in another space: the patterns of financial transactions/ exchanges in what I have labeled the "Móng Cái little Wall Street."

\section{“Móng Cái little Wall Street": money transfer procedures}

Exploring the financial modalities employed by Chinese and Vietnamese traders once they have reached a business agreement offers an alternative approach to the delicate 
concept of trust and distrust; a concept that is put at stake since it obviously affects daily cross-border interactions between communities, and feeds the challenge of implementing a national economic agenda at the ground level.

Most Chinese traders who arrive in Móng Cái and Dongxing have an ambition to engage in cross-border trade and raise money as quickly as possible. Pursuing this aim, however, they must deal with one important and pragmatic question: money transfer. For those engaged in import-export businesses, modalities of capital exchange may well be similar to those experienced during business operation in China, as long as they agree to pay the high fees charged by financial institutions in relation to currency exchange. For many traders who choose to avoid these troubles and expenses, including small-scale traders operating in the Móng Cái Central Market, an alternative option is to adopt another system. Understanding and adjusting to local everyday practices in terms of currency exchange, private banking and credit management is crucial to the implementation of the business projects of Chinese traders.

In the realm of small-scale trade, generally no contract is signed between a supplier and a customer. Each party simply maintains a record of orders in a well-kept notebook. Hence, word and trust constitute the sole basis of business deals: trust in the Chinese wholesalers' ability to supply the goods on time, with the expected quality at the agreed price and according to a regular logistical procedure; and trust that the Vietnamese customers will collect their orders, will pay according to the agreed-upon schedule and will refrain from changing their mind or returning unsold goods. Payment is of course the dominant link in this logistic, since each link in the commodity chain between a factory in China and a retailer in Vietnam requires some form of investment, and imposes responsibilities on the wholesalers and their shipping partners. At any time, there exists the potential that one of these links will fail to respect a contract and put at risk the business deals of many intermediaries. Money transactions are administered according to well-established rules that suppose an accurate evaluation of risk on the part of those who use informal banking systems.

In Móng Cái, this system is administered and controlled by a large group of Vietnamese women established inside the markets, on street corners and in the notorious currencies market that I have labeled "Móng Cái little Wall Street" (Xie 2000). If one wonders why women dominate the currency trade, people unanimously answer that Vietnamese men in general are very poor money managers and money wasters. As a consequence, women are usually in charge of the family budget and other money transactions such as private loans, lotteries, or underground banking systems. Those women operating in Móng Cái come from different backgrounds and generally work with regular customers who, once their deals have tested their mutual trust, may introduce new customers, following a snowball system. These women use their personal bank accounts in Vietnam to deposit and withdraw currencies according to their customers' needs. They make profit by lending capital without paperwork, charging an exchange/interest rate lower than in the bank; they raise their incomes by getting commissions. Both parties find the system efficient, fast and flexible. The currency exchange rates are adjusted daily, the interest rate is negotiable according to customers' situations, and all agreements are based on each party's word.

Van is one of the black-market money actors. She is a Vietnamese woman who lives in a common-law marriage with her Chinese husband in Dongxing. Originally the translator in her husband's electrical appliance shop, she decided to become a moneychanger to sustain their family after the business went bankrupt. Although this new role allows her greater flexibility and more time, in addition to providing her with a higher 
income, risk constitutes a delicate aspect of her position. Every day, Van meets her customers either at their workplace (shops) or at her rented space in "Móng Cái's little Wall Street." There, in a basic open space simply covered by a roof, dozens of experienced moneychangers spend their day endlessly counting large amounts of cash. Seated on an elevated platform covered with a bamboo mat, each woman occupies approximately (Figure 2) one to two square meters, which is enough space to sets up a metallic box (locked), an electric fan, a calculator, a handy bill-counter, and a phone charger, as well as to sit and welcome customers. The intrusion of strangers (such as a foreigner) into this space is usually met with indifference and closed expressions on these women's faces: time is money, and operational confidentiality is the rule. This is where many cross-border traders, previously introduced by regular customers, exchange their cash into their neighbor's currency, eliminating the need to negotiate the regular banking process. Van explains how it works:

The simplest way for a Vietnamese client to pay a Chinese wholesaler for instance is transacting the money via the bank account of a money-changer like me. In this case, I receive the due amount in đồng ${ }^{1}$ (VND) in my account; I then withdraw it, change it into Chinese currency [according to the black market rate] and hand it in cash to the Chinese boss. Alternatively, I can deposit it into his Chinese account, ${ }^{2}$ or make a transfer in yuan (RMB) from my own Chinese account to his. Usually each Chinese boss and Vietnamese client works together in association with one or several money-changers. We require trusting relationships, which take time to establish. In this type of transaction, I don't make a profit

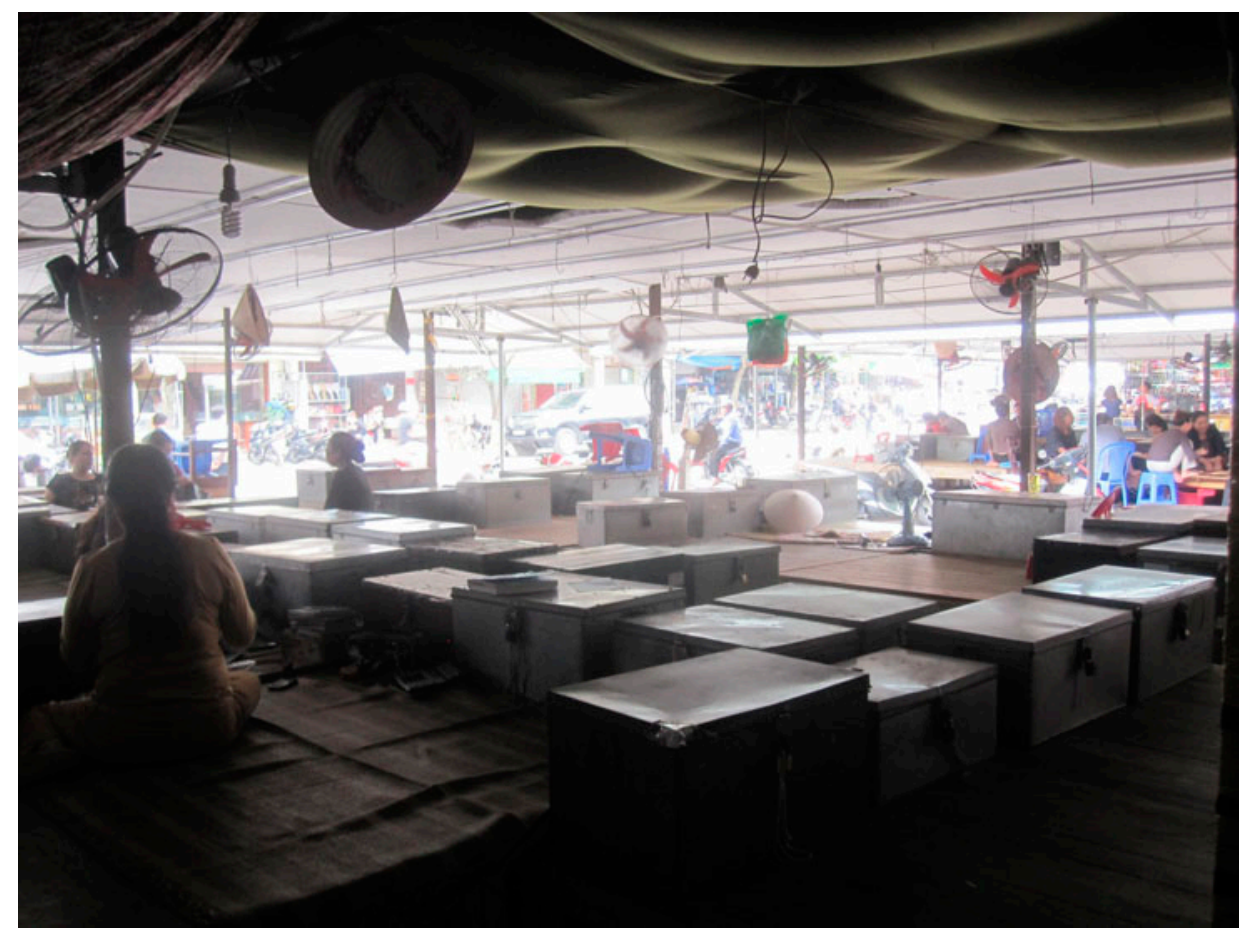

Figure 2. The end of the day in "Móng Cái little Wall Street" (photograph by Caroline Grillot 2013). 
by providing this service in itself, but I do make a profit when changing the money at the black market rate.

In appearance, the process seems easy although one may wonder why bother when it is legally possible for any Chinese or Vietnamese citizen to open a bank account in the neighboring country. Van reveals the interesting outcome of this procedure:

The advantage is that, in the official financial system, there will be no visible connection between a buyer and a supplier. The only visible track of a transaction will be between the Vietnamese client and myself at the Vietnamese bank, and possibly between the Chinese wholesaler and myself at the Chinese bank. Such an easy transfer doesn't require any explanation at the bank. The transaction is simple, but if I agree to pay the whole amount in advance, I will actually lend money to the Vietnamese client, who will then need to reimburse me with rather high interest. That way, I can also make some benefit. Previously, interpreters also served as face-accounts for Chinese bosses but there were a few scandals involving interpreters who flew off with money from deals in their account. So now Chinese bosses prefer to make arrangements with professional moneychangers. It's a question of trust.

Therefore, the whole procedure is based on trust, that is, on the tacit acceptance of the money changer's financial conditions, and potential deception. However, in the end, according to my informants, this procedure remains cheaper than direct international bank transfers and guarantees the necessary invisibility of small-scale trade that relies mainly on smuggling: no track, no direct link between business partners, and no tax. How money changers manage to avoid controls resulting from the constant activity in their bank accounts remains uncertain; this is a matter that Van elides by simply stating that "banks are too busy with large financial transactions to care about our small money management." When she says "small," she is actually referring to a few tens of thousands of yuan. Van seems to insinuate that consequent bank transfers may become the subject of banks' scrutiny, although more investigation is required to support the idea of a differentiated degree of flexibility on the part of local bank regarding money flows.

Money flows are such that, when making a decision on a deal, all cross-border traders must find a balance between the absence of formal tracks and the consequent financial benefit of tax evasion on the one hand, and the risk of facing unscrupulous customers or go-betweens, with the potential subsequent loss of investment and stock, on the other hand. Relating to what Parry and Bloch remind us in their discussion on the concept of gift, money is not a neutral instrument; it also "contains and transmits the moral qualities of those who transact it" (Parry and Bloch 1989, 8). Street money traders, as well as their customers, have equal chances to find and bond with reliable business partners, although they may also fall into traps. But their sense of solidarity and their ability to communicate usually spread the news about bad payers. News of unfortunate endings to collaboration also prevents a trader who failed to honor a contract to find local trustworthy moneychangers, and this may seriously jeopardize his/her business as well. Trust is an invisible and hardly controllable factor in trade, especially cross-border trade, because one of the two actors of a deal can easily disappear into one's own country without fear of being investigated or followed. But disappearing might not imply going away. Several local traders informed me that when someone often changes his/her mobile phone number, it gives a warning. This person is trying to avoid being found and forced 
to face the consequences of previous trickeries. The system works well enough to allow the development of economic exchanges, but in general, mutual cautiousness remains the rule.

\section{The "trust" capital}

"Trust is the trustfulness of a trustor: the extent to which the trustor is willing to take the risk of trust being abused by the trustee" (Buskens 2002, 8).

The notion of trust has been debated in many disciplines of social science, which have all approached it from different angles, without agreeing on any clear and definite definition that entails every dimension of what is, eventually, a presumption granted to an Other. However, in the introduction of her comprehensive review of trust-related literature, Barbara Misztal (1996) pointed out a few points that are enlightening in our understanding of the sensitive business relationships at stake in the Sino-Vietnamese border trade. First of all, trust is a social mechanism, or an instrument of social organization. But its impact can only be measureable on the long term: "the trust features... require a time lapse between one's expectations and the other's action" (1996, 18). And as our case study reveals, trust "always involves an element of risk resulting from our inability to monitor other's behavior, from our inability to have a complete knowledge about other people's motivations and, generally, from the contingency of social reality" $(1996,18)$. Such inability becomes exacerbated in a context of small-scale trade carried on without formal proper contracts, or reliance on legal tools that protect sellers and customers from various forms of abuse. Being a fundamental component of informal trade between Vietnamese and Chinese, trust remains nevertheless extremely difficult to negotiate along the routine of daily practices, even to Chinese traders known for the dynamism of their economic activities, and their efficiency regardless of their methods.

Many authors have studied the Chinese business system, and it is not the purpose of this article to explore its complexity further. Rather, it concentrates on the manner in which Chinese traders articulate the difficulties they encounter in Vietnam, especially when the business ethics on which they rely show their limitations within this challenging context, as well as their capacity to overcome such obstacles in their pursuance of commercial projects.

Barton (1977) conducted research among the Chinese community in southern Vietnam in the early 1970s, exploring the strategies and requirements on which their activities were grounded. He assessed the importance of the widely acknowledged notion in Chinese economics of xinyong. Chinese business practices build on the concept of xinyong, which the author defines as "the basis for a particular type of business strategy which emphasizes personal relations and the maximization of long term advantage" (Barton 1977, 150). Xinyong usually translates as "trust," but Tong $(2014,13,14)$, analyzing the contemporary Chinese community of Singapore, also suggests that "xinyong should be translated as integrity or credibility or reputation and character of a person" and that xinyong is a "dynamic concept, a mode of adaptation for operating in particular historical and environmental conditions."

Chinese traders who operate in Móng Cái typically mention two spheres of interaction with Vietnamese where, according to their experience, the issue of xinyong becomes problematic, to a more consequential extent than is the case within the framework of their interaction with other Chinese: the negotiation process and the credit 
system. In the first sphere of interaction, as the examples above have shown, a trader seeks trust in his potential partner in order to establish a long-term business relationship. In the circle of Chinese traders, be they within China or among overseas communities, projections of future deals rely mostly on a delicate evaluation of xinyong. A potential new partner's behavior, words and actions are put to the test. According to Tong, the importance afforded to xinyong, and the preference of Chinese traders for oral agreements and contracts, particularly in a border context where a large proportion of smallscale trade uses informal channels, originates from a lack of trust in legal systems:

Vis-à-vis this lack of systems trust (or systems distrust), Chinese traders came to rely on personal trust or xinyong, preferring to work with individuals whom they personally trusted and seeking to bring new acquaintances within their personal realm of familiarity. Much energy is invested in establishing and nurturing personal relations or guanxi and developing good xinyong, which is a personal property (Tong and Yong 2014, 57).

Since the early stage of the socialist-oriented market economy in Vietnam - the Đổi Mới policy implemented in 1986 - access to formal financial institutions has been difficult for most private entrepreneurs building up their own firms (McMillan and Woodruff 1998). Reliance on informal credit systems was observable two decades ago and is still considered as a preferred means of gaining access to start-up capital and investment funds. Trust is thus a fundamental value to cultivate and maintain, in addition to the avoidance of customers who renege on commitments. One possible method through which to measure the degree of trust a trader places in a customer is the level of credit granted. Consequently, as observed by McMillan and Woodruff in their research, one way for a customer to test his/her partner is to intentionally delay payment to increase the debt, in order to evaluate how much more credit he/she could gain without arousing suspicion and jeopardizing the trustful relationship $(1998,9)$. While such behavior (also noticeable in Móng Cái's market transactions) is understood as a testing tactic from the viewpoint of the Vietnamese customer, it is nevertheless easily misunderstood and may produce the opposite of the desired effect among Chinese traders. While several of my informants acknowledged that tolerating payment delay might be necessary, and over time it was possible to build up sufficient confidence in a customer to maintain an effective business partnership, many others felt profoundly disturbed and annoyed by this game. Obviously, the nature of border trade - unreliable, risky, and volatile (at least regarding small-scale trade) - places enormous pressure on traders, whose purpose is to quickly raise profits with immediately efficient deals, rather than working on establishing long-term partnerships with customers they sometimes barely know. The interactions that traders maintain with their various partners (suppliers, shippers, customers) are often limited to distant phone calls, and negotiation through mobile and slippery intermediaries.

The social distance that is inherent to the specific nature of some cross-border business partnerships complicates the reliance on such usual principles as the examination of reputation. Indeed, reputation is probably one primary way to measure trustworthiness (Tong 2014). However, here again, Móng Cái's market activities take place against a rather particular backdrop of actors' mobility that does not ease access to personal background. Both Chinese traders and Vietnamese customers deal with each other with the knowledge that, upon the occurrence of any dispute over goods quality, payment or delivery, the easiest way out of trouble is to vanish far from the border in one's own country, leaving no option for negotiation or retaliation. 
Some behaviors act to provide an indication of a partner's reputation. Several experienced traders explained that, when a partner suddenly changes his/her phone number without notice, this means that he/she has reneged on a commitment, be it financial (debt, credit) or related to contract follow-ups. Another indicator is the period of time in which an individual has worked within a specialty, which can reveal a lack of ability to maintain a business, and sustain connections and partnerships, regardless of environment, crisis or financial difficulties. However, when Chinese traders are strict with Vietnamese customers who have failed to respect a contract, this may bring a bad reputation among their other local customers, hence threatening their business sustainability in a foreign environment.

In the way Chinese traders articulate the challenging behavior of their Vietnamese customers, mistrust may sometimes lead to charges of dishonesty. However, from a Vietnamese point of view, such business conduct should not be used to question the honesty of either party. Mr. Guan is a Vietnamese seafood dealer in Móng Cái. His Chinese family background allows him some analytic distance from which to view these financial movements:

In our business field, we can't pay cash for daily transactions. That would be costly and unsustainable. Consequently we establish a credit system. We must sell the merchandise before being able to raise a profit, and then pay our bills. Chinese traders who can pay cash have a clear advantage over us. They have stronger financial means than we do. Such a system could not be implemented realistically in Vietnam, and so we must indebt ourselves and wait for an opportunistic moment to settle our debts. I myself use the bank to make more profit. I pay my suppliers [fishermen] once every two weeks. In the meantime, I deposit my profits in the bank so they can yield profits, and then later I pay my suppliers. So I make more profit than if I had paid them immediately after selling the fish to my customers. I see nothing wrong here.

When asked why their Vietnamese partners waited a relatively and variably long period before settling a bill, several traders and intermediaries, well informed in financial practices in Vietnam, also mentioned this procedure. They suggested that placing short-term investments in the bank produced sufficient financial interest to make this practice worth following. To some needy traders (in goods or currencies), the small profits made from this practice made it worth the risk of irritating their Chinese trading partners and jeopardizing the xinyong capital they have invested in their business contracts.

From the Chinese perspective, particularly for those who do not yet understand - or accept - the subtle financial mechanism at stake, delaying payment is actually interpreted as a means of forcing them to more flexible and tolerant than they would have been had their partner also been Chinese. From their standpoint, being tested is being controlled. "Mei banfa [there is no other way]" is a common answer to enquiries concerning the Chinese traders' manner of tackling recurrent difficulties with indebted clients reluctant to pay in good time. Patience, tolerance and adjustment to local practices are the end result of their helpless position, and this is especially the case for those who cannot afford to turn down customers, or turn to another business project, in a very competitive commercial environment.

While Chinese traders feel disrespected because their Vietnamese customers fail to act in accordance with Chinese business ethics, their Vietnamese counterparts believe their flexibility in terms of finance and operation is limited by structurally unbalanced trading conditions due to a rather different level of commercial development and experience. Misunderstandings and disagreements in practice lead both parties to nurture the 
conviction that the other deliberately and mutually abuses their position, resulting in frustration and a compulsive focus on the notion of trust as the sole explanation for the other's failure.

\section{Conclusion}

Despite its dynamics, the ongoing commercial activity in Móng Cái actually hides internal flaws of trade practices and consequent infringements to trustful partnership. New cohorts of traders keep replacing those who failed, and give the illusion that conducting sustainable business is also possible under informal economic conditions, that is to say, those based on trust rather than contract; but the issues remain. In line with recent ethnographies on credit and debt that have shown how the "credit/debt nexus is productive of social ties, allegiances, enmities, and hostilities" (Peebles 2010, 234), this article analyzes Sino-Vietnamese trading collaboration through the modalities of their financial transactions. It highlights that behind the complexities of maintaining trust between communities of traders, the ground that sustains their relationship of reciprocity is constantly renegotiated.

Meanwhile, scholarship on border trade between China and Vietnam often emphasizes how the complex and asymmetric historical relationship between these countries frames the nature of border community interactions. However, as Kirsten Endres (2015, 734) stresses in her account of small-scale traders in Lào Cai, another Vietnamese border town, the border

emerges as a productive site, in providing not just access to economic opportunity but also a boundary through and across which identities are shaped. As complex, multidimensional processes that involve both short-lived interactions and carefully cultivated relationships with the neighborly Other, these borderland identities and alterities are continuously in the making.

Surely, such relationships are mirrored at the level of trust Chinese and Vietnamese traders accredit each other when they carry out their borderland activities. Chinese activities display the prosperous image of their nation's economic development, and their ambition to expand their power in the region. In response, unable to compete with the same resources of their neighbor, the Vietnamese often adopt a defensive behavior built on a strong ability to negotiate their resources under their own conditions.

Maintaining a reliable trustful relationship among trade's stakeholders is at the core of the development of economic cooperation. But according to Móng Cái's Chinese and Vietnamese cross-border traders, this still remains only a wish. Drawing from their experiences, traders elaborate a discourse on trade ethics as understood in Chinese and Vietnamese business cultures. This discourse is regularly raised as a safeguard against the breach of trust they believe they are frequently the victims of in the course of their business dealings.

However, one should not underestimate such practices as modalities of negotiation and financial transactions in small-scale trade - the ground for mutual benefits - in evaluating the capacity of Chinese and Vietnamese traders to eventually overcome structural difficulties, including cultural differences, in conducting business. While the Chinese traders may understand the Vietnamese methods as irregular and unethical when it comes to evaluating their working principles, they also enjoy some convenience, as in the case of money transfer procedures. The Vietnamese may keep a cautious attitude toward their Chinese suppliers by imposing their rules on their 
territories, but they benefit from a growing border-trade that compensates for the lack of industrial products made in Vietnam. In the pursuit of similar goals, traders' efforts to adjust to one another's methods reveal their degree of understanding, and the nature of their tacit complicity in their attempt to maintain their own business logistic regardless of the limits imposed by national policies, institutional regulations and stereotypes.

Current everyday practices suggest that the shadows of the past and remaining conflicts may not deeply affect the actors of cross-border trade. Chinese migrant traders, the largest group of business people who operate in Móng Cái markets nowadays, mostly come from outside the borderlands and do not necessarily relate to the specificities of local history. Their feelings of distrust towards their partners emerge from uneven commercial experiences, communication misunderstandings, rumors, competitive pressures, and culturally marked approaches to capital management, rather than from political rhetoric. Still, their mutual dependency eventually makes their partnership improve toward more stability despite discrepancies, making the development of border cities such as Móng Cái a "work in progress."

\section{Acknowledgements}

This article has greatly benefitted from constructive comments received at the 4th Conference of the Asian Borderlands Research Network, Hong Kong, City University of Hong Kong (December 2014) "Re-openings, Ruptures, and Relationships" (8-10th December, 2014). Special thanks go to the anonymous reviewers, and to my colleague Kirsten Endres for their valuable comments and suggestions on the earlier drafts. I am most grateful to the Institute of Cultural Studies (Vietnam Academy of Social Sciences, Hanoi) for their support, in particular to my research assistant Dinh My Linh for her patience, help and insights during fieldwork, and to all my Chinese and Vietnamese informants for their trust.

\section{Funding}

The fieldwork for the research presented in this article was made possible by the research funding provided by the Minerva Program of the Max Planck Institute for Social Research (Germany).

\section{Notes}

1. The Đong (VND) is the currency of Vietnam.

2. Van is Vietnamese but she resides in China (Dongxing), which allows her to open a Chinese bank account.

\section{Notes on contributor}

Caroline Grillot is currently holds a research associate position in the School of Social Sciences at the University of Manchester. Her research interests are social margins in China, and have included ethnic folklorisation, underground artistic communities, and cross-border Sino-Vietnamese marriages (Grillot, Volées, Envolées, Convolées, Paris: Connaissances et Savoirs, 2010). She is currently preparing an updated manuscript based on the topic of her doctoral dissertation.

\section{References}

Abraham, Itty, and Willem van Schendel. 2005. "Introduction: The Making of Illicitness." In Illicit Flows and Criminal Things: States, Borders, and the Other Side of Globalization, edited by Willem van Schendel and Itty Abraham, 1-37. Bloomington and Indianapolis: Indiana University Press. 
Barton, Clifton Gilbert. 1977. "Credit and Commercial Control: Strategies and Methods of Chinese Businessmen in South Vietnam." PhD diss., Cornell University.

Buskens, Vincent. 2002. Social Networks and Trust. New York: Kluwer Academic Publishers.

Chan, Yuk Wah. 2013. Vietnamese-Chinese Relationships at the Borderlands. Trade, Tourism and Cultural Politics. London and New York: Routledge.

Cheung, Siu Woo. 2000. "Regional Development and Cross-Border Cultural Linkage: The Case of a Vietnamese Community in Guangxi, China." In Where China Meets Southeast Asia: Social and Cultural Change in the Border Regions, edited by Grant Evans, Christopher Hutton and Kuah Khun Eng, 277-311. Singapore: Institute of Southeast Asian Studies.

Endres, Kirsten W. 2015. “Constructing the Neighbourly 'Other': Trade Relations and Mutual Perceptions across the Vietnam - China Border." Journal of Social Issues in Southeast Asia 30 (3): 710-741.

Hai, Chau Thi. 2000. "Trade Activities of the Hoa along the Sino-Vietnamese Border." In Where China Meets Southeast Asia, edited by Grant Evans, Christopher Hutton and Kuah Khun Eng, 236-253. Singapore: Institute of Southeast Asian Studies.

Horstmann, Alexander, and Reed L. Wadley. 2006. "Introduction: Centering the Margin in Southeast Asia." In Centering the Margin: Agency and Narratives in Southeast Asian Borderlands, edited by Alexander Horsmann and Reed L. Wadley, 1-24. New York and Oxford: Berghahn Books.

McMillan, John, and Christopher M. Woodruff. 1998. Networks, Trust and Search in Vietnam's Emerging Private Sector. Mimeo: University of California.

Misztal, Barbara A. 1996. Trust in Modern Societies: The Search for the Bases of Social Order. Cambridge: Polity Press.

Moore, Mick. 1999. "Truth, Trust and Market Transactions: What Do We Know?" Journal of Development Studies 36 (1): 74-88.

Parry, Jonathan P., and Maurice Bloch. 1989. "Introduction: Money and the Morality of Exchange." In Money and the Morality of Exchange, edited by Jonathan Parry and Maurice Bloch, 1-32. Cambridge: Cambridge University Press.

Peebles, Gustav. 2010. "The Anthropology of Credit and Debt." Annual Review of Anthropology 39: $225-240$.

Stammler-Gossmann, Anna. 2012. “Winter-Tyres-for-a-Flower-Bed': Shuttle Trade on the Finnish-Russian Border." In Subverting Borders: Doing Research on Smuggling and Small-Scale Trade, edited by Bettina Bruns and Judith Miggelbrink, 233-255. VS Verlag für Sozialwissenschaften / Springer Fachmedien Wiesbaden GmbH.

Tong, Chee Kiong. 2014. "Rethinking Chinese Business." In Chinese Business. Rethinking Guanxi and Trust in Chinese Business Networks, edited by Chee Kiong Tong, 1-20. Singapore: Springer.

Tong, Chee Kiong, and Pit Kee Yong. 2014. "Guanxi Bases, Xinyong and Chinese Business Networks." In Chinese Business. Rethinking Guanxi and Trust in Chinese Business Networks, edited by Chee Kiong Tong, 41-61. Singapore: Springer.

Wilson, Thomas M., and Hasting Donnan. 2012. "Border and Border Studies." In A Companion to Border Studies, edited by T. M. Wilson and H. Donnan, 1-25. West Sussex: Wiley-Blackwell.

Xie, Guangmao. 2000. "Women and Social Change along the Vietnam-Guangxi Border." In Where China Meets Southeast Asia: Social and Cultural Change in the Border Regions, edited by Grant Evans, Christopher Hutton and Kuah Khun Eng, 312-327. Singapore: Institute of Southeast Asian Studies.

Zhang, Juan. 2011. "Border Opened up: Everyday Business in a China-Vietnam Frontier." PhD diss., Macquarie University. 